\title{
The Epistemology of Fiqh-Science and Its Implementation in Contemporary Fiqh in Indonesia
}

\author{
Anies T Kuncoro \\ Syariah Department \\ UNISSULA \\ Semarang, Indonesia \\ anieskuncoro982@gmail.com
}

\author{
Muchamad Coirun Nizar \\ Syariah Department \\ UNISSULA \\ Semarang, Indonesia \\ choirun.nizar@unissula.ac.id
}

\begin{abstract}
Religion and science are two different things that are believed by some people, especially, from the clergy from the same source, namely God. The offense of the two is always an exciting topic of discussion by scientists. Fiqh or with other terms is called Islamic law as part of the Islamic religion which is also interesting to discuss its offense with science. Means of science in its determination must support the continuity of figh in the modern era. This article tries to uncover the relationship between fiqh and science in the realm of epistemology and to examine the two disadvantages in contemporary fiqh in Indonesia. In the realm of epistemology, fiqh and science are human products as subjects. Both are different in taking from the source. Fiqh comes from revelation while science from nature. In essence, fiqh is also a dynamic area in Islamic law though it is possible to be supported by science as a means of achieving relative truth. In practice, fiqh and science experience an offense in the case of contemporary Islamic law in Indonesia. Determination of the direction of the Qibla using modern methods is one of them. Recently, the determination of the Rubella vaccine law through MUI Fatwa No. 33 of 2018 concerning Rubella Vaccine is the implementation of scientific involvement in the determination of fatwas which incidentally are part of fiqh.
\end{abstract}

Keywords: Epistemology, Fiqh, Science, Implementation, Indonesia

\section{INTRODUCTION}

Science and religion later became an exciting issue to be discussed by various groups from the beginning of the relationship between the two, the offense of both of them to the competition between the two in proving the truth of each between science and religion. John F. Haught even explained the relationship between the two using four different approaches, namely the theory of conflict, contrast, contact, and confirmation. Religion and science relations in the perspective of conflict have long occurred when acceptance of the truth one of them is a rejection of the other's truth. Whereas in contrasting perspectives, the relationship between religion and science ultimately leads to a dichotomy of the respective regions between science and religion. Science deals with nature and its laws, while religion deals with metaphysical themes. Religion and science relations contact perspective when in some cases, there is an offense between science and religion. While the confirmation perspective in the relationship between science and religion appears in several types of research which led to the creation of science that is meaningful with a religious basis. [1]

The tendency of experts to examine the relationship between religion and science is increasing as more criticism addressed to modern science with many emerging diseases, global pollution, and the threat of nuclear warfare and so on. One of the leading causes of all this is modern science. Although it later acknowledged that the need to separate science from the pure was born from the desire and tendency of humans to find the truth, with science which was born from the desire to enjoy pleasure, comfort, and power. Though, science is tried to connect in a confirmation perspective with religion. At least to understand that from science it rooted a belief that the universe is a totality of objects that experience rational arrangement. A religion that originates in trust ultimately encourages followers of a religion to always live the trust continuously by way of traveling in the framework of scientific discovery.

Discourse on the relationship between science and religion in this case, more specifically on the religion of Islam at least raises three patterns of interaction, among others, the Islamization of science, the science of Islam and Islamic science. Many institutions including higher education institutions have now implemented the process of Islamization of science. As for Islamic science itself, it has long has conceived by contemporary figures such as Hossein Nasr and Ziauddin Sardar. [2]

Sharia and fiqh as an inseparable part of Islam are also affected to connect with science. It is undeniable that the continuity of fiqh in the modern era cannot be separated from science. Science has its role in the figh area as a means, aids to alternatives that can help the implementation of fiqh concepts. Vice versa, fiqh has a role in science as legalization for science. This paper will discuss specifically fiqh epistemology and science so that the relationship between the two will be seen.

\section{EPISTEMOLOGY OF FIQH AND SCINCE}

Fiqh is a branch of law that has other identical names, namely sharia and Islamic law. Fiqh is often merely defined as Islamic law and is sometimes very synonymous with sharia. Etymologically, the word fiqh means al fahm ad daqiq whose meaning is deep understanding. While fiqh concerning fuqaha 'is often defined as follows:

[3] معرفة الاحكام الشر عية التي طريقها الاجتهاد

Meaning: Knowing the laws of the Sharia by way of ijtihad.

Fiqh is one of the branches of law whose studies revolve around the laws of the Sharia or the laws of God. From this 
definition, it shows that fiqh primarily includes knowledge that functions for legal reconciliation on something or tashdiq. [4]

Concerning science, one factor that is very visible from the decline of Muslims in modern times today is due to lagging in technological progress. While if we open the golden sheet of Islamic civilization, it will be very easy to find Muslim scientists with all the scientific tools like bayt al hikmah, observatories, hospitals and so on. Even for an extended period, Islamic civilization became the most productive civilization for scientific development. [5]

Look at the definition of science etymologically; then science means science in general. [6] Science itself is an absorption word from the word science in English, which means natural sciences. The meaning of natural science is the sciences that study the phenomena of the universe with all its contents. It includes basic sciences such as biology, chemistry, physics, and astronomy and applied sciences such as pharmacy, medicine, agriculture, dentistry, optometry, and others. [7]

According to Pervez Hoodbhoy, science has a value of progress that originates from itself. That is what causes science always to live and distinguish itself from other humanitarian institutions such as religion, philosophy, and art. If religion based on eternal truths that have never experienced reduction and are also added by later generations, then science exists in a world different from its cumulative character and its impermanence. [8]

\section{A. Epistemology of Fiqh}

Epistemology as one aspect of science comes from two foreign words, episteme and logos. Both terms mean knowledge. Epistemology often interpreted as a theory of science. That is, epistemology discusses knowledge and ways or methods to get it. To get knowledge, must go through a procedure known as the scientific method. [9] Epistemology is part of the philosophy that talks about the occurrence of knowledge, the source of knowledge, the origin of knowledge, boundaries, traits, and validity of knowledge.

The epistemology of fiqh, it can be seen from the definitions that generally known among fuqaha. That is

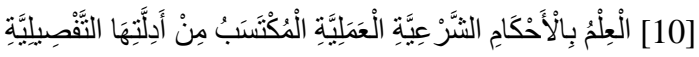

Meaning: Science with the specific discussion in the form of sharia laws which are amaliah and taken from their detailed arguments.

From the definition that has widely understood, fiqh is a part of science or science that is scientific and has certain objects of study and rules. The object of study in fiqh is everything that is done by people who are subject to legal burden, or in the language of the mukallaf Sharia. The object more specifically only revolves around something that is done by the mukallaf limbs, not heart practice, because the area of fiqh is physical, not non-physical. Fiqh based on two sanctified texts, the Quran and the Sunnah. Because an understanding of the Quran and assault by Muslims in a different time and space with the Messenger of Allah is complicated, it needed a tool in the form of the opinion of the Ulama resulting from ijtihad contained in fiqh. Fiqh aims to carry out the commands of Allah as the maker of the Sharia and stay away from His prohibition with the benefits orientation both in the world and in the hereafter. So in simple terms, fiqh is a standard conclusion, the result of ijtihad Ulama which is sourced from the Quran and Sunnah and methodologically from ijma', qiyas and other methodologies. [10]

The term fiqh does have several identities that are almost the same as sharia, Islamic law, Islamic jurisprudence, and others. The difference between fiqh and sharia is regarding certainty and consistency. Sharia is definite and unchanging while figh is changing according to the situation and conditions. Besides, the differences between the two are also found in the essence that is different from each other. Sharia contains general laws of God in the Quran and Sunnah by laying down basic principles, whereas fiqh is an understanding of sharia as a response to the problems of the people and is specific. [11]

From the explanation of differences in fiqh and sharia, it can be seen that the epistemological aspects of fiqh which are related to the source are the Quran and Hadith as primary sources and ijtihad as a secondary source. Both the Quran and the Hadith are the main sources in fiqh, considering that both are the will of the Prophet Muhammad to always be held firmly by Muslims wherever and whenever.Ijtihad is defined by Al Ghazali as quoted by Wahbah Az Zuhaili as an activity of extracting syara law 'from the arguments of syara' (Quran and hadith). [12] Ijtihad in the sense of trying to extract Islamic law can use various legal methods that have been formulated by the fuqaha 'such as qiyas, maslahah mursalah, Istihsan, "urf and so on.

In other terms, methods in legal terms are not categorized as sources but methods or methods of law retrieval from texts. Therefore, what is worth mentioning as a source of Islamic law or the source of fiqh is the Quran and hadithWhile some legal methods used to explore Islamic law from nash include:

\section{1) Qiyas}

In the study of Islamic law, Qiyas by many scholars designated as one of the sources of Islamic law, in addition to the Quran, Hadith, and Ijma'. [13] Qiyas, which is usually translated by reasoning through analogy, is born from the tradition of using Ra'yu to solve essential problems. This tradition is not new in Islam. The use of Ra'yu has been common in mainland Arabia since pre-Islam.

Qiyas is defined by Al-Ghazali in al-Mustashfa as:

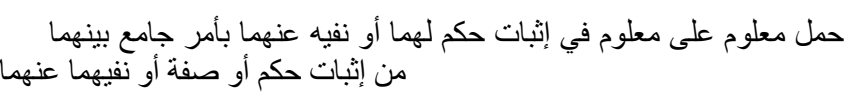

Meaning: "Bring out something that is known to something that known regarding establishing the law in both or nullifying the law of both because there is the same thing between the two, in the application of law or the elimination of law." [14]

Furthermore, al-Ghazali said that qiyas is also called nazhar wal ijtihad (free reflection and reasoning), because it involves reflection; It is also called the argument (clue), because it shows legal provisions, and is called 'final' (cause and effect), because it consists of legal reasons ('illat). Because 'illat (because) is the main component of qiyas, sometimes qiyas is also called'illat. [15] 


\section{2) Mashlahah}

Mashlahah in the tradition of the study of Ushul fiqh recognized as one of the methods used to explore and discover God's law. When there is a need for legal certainty or when there is powerlessness, and even methodological fragility, mashlahah with all the authority attached to it is present and active in resolving various legal issues at hand.

It can be said, among the many results of being Islamic law (fiqh), not a few are mashlahah products. Though it is not excessive if mashlahah deserves a great appreciation that can bridge God's products (sharia law) with human products (ijtihad fiqhiyyah). [16] The ability of the mashlahah as a facilitator and mediator, shows that the authority he has is not worthy of neglect and neglect. It can be seen from the mission carried out by mashlahah, which connected with efforts to understand the purpose of God and the Prophet in creating and shaping Islamic law. Essentially, mashlahah is the core (spirit) of every Sharia device. Mashlahah is the leading spirit of the purpose of all provisions of orders and prohibitions in the Sharia (maqashid shariah).

Al-Ghazali gave the limit that mashlahah as it was an effort to realize benefits and prevent mudlarat. In this limitation, Al-Ghazali emphasized that what meant is not mashlahah based on human taste, but which oriented towards the maintenance of the goals of syara' (maqashid shariah). Furthermore, Al-Ghazali described the maqashid shariah to focused on five main things, namely the guarding of religion, soul, mind, property, and descent. [14] In connection with the definition of Al-Ghazali, the Ash-Syathibi with the maqashid shariah theory asserts that the benefit of religion (ukhrawi) and the benefit of the world is a building of theory based on the five main issues mentioned by Al-Ghazali. [17] Inspired by Al-Ghazali also, Abdul Karim An-Namlah defined mashlahah as "the desired benefits of sharia" for his servant, in the framework of the five principal elements; religion, soul, mind, property and descent. "Then the derivative element of all that included in these five main cases falls into the category of mashlahah. [18]

\section{3) Istihsan}

Istihsan in language, comes from the basic word hasana which means good or beautiful, the meaning is something that is considered good and beautiful. [19] Whereas Istihsan according to the term is the transfer of a mujtahid from the demands of real qiyas (jali) to qiyas khafi (vague), or from the argument of kulli to the law of tahshish because of the existence of a proposition that causes the mujtahid to divert the results of their thoughts and emphasize the transfer of law. [20]

\section{4) Sadd adz Dzari'ah wa Fathuha}

The word adz-dzaria means an intermediary etymologically. [21] This taken from the root of the word Dzara'a. Al-Jauhari said that the primary meaning of the word was nothing but like stretching hands. [22] Thus from the fraction of this word, the term adz-dzira appears, meaning the limbs of the hands from the elbow to the fingertips. In subsequent developments the word adz-dzaria was adopted by the term ushul figh, which used as one of the legal methodologies. The understanding of adz-dzaria for the majority of expert scholars of ushul figh has more implications for the narrowing of the meaning of its primary meaning, while some other scholars are more directed towards the expansion of meaning. Thus, that in the study of ushul fiqh adz-dzaria is defined in two versions; adz-dzaria al-khashshah and adz-dzaria al-'ammah.

Adz-dzaria al-khashshah (specific means) that is all intermediaries that are permitted, whether intended as an intermediary for damage or not, but its function as a cause of interpretation is more dominant, and the danger is higher than its usefulness or benefits. It is the meaning of adz-dzaria which is mostly used by usul ulama. Besides, Al-Qurthubi called it a term for a person who is not banned, but it feared that it would cause a case that is forbidden if done. From all of them, AshSyathibi affirmed that this adz-dzaria is a matter of mashlahah which used as access to mafsadat. [17]

Adz-dzaria al-'ammah (General Means) is everything that can be used as an intermediary for something else, whether it is halal or haram. In a sense, if it becomes accessible to danger, even if it is closed (sadd) it is permitted (fath) if it is an access to the interests that justified according to syara'. [23] According to Wahbah Az-Zuhaili, the barometer adz-dzaria depends on the scales of mashlahah and mafsadah. adz-dzaria will be obliged if it becomes an intermediary of compulsory cases, such as ablution as wasilah prayer. Alternatively, it is forbidden to be an illicit mediator, such as stealing to provide for a family without critical conditions. Though it can also change, if you become an intermediary for things that are changed, such as doing a lawful business to enjoy life. [12]

\section{5) 'Urf}

'Urf means everything that has been familiarized by the community and has run continuously in the form of words and deeds. 'urf is also called custom. [24] 'Urf plays an important role as one of the methodologies within the framework of building Islamic law, which is engaged in the problem of interaction and friction between religion and tradition or customs that develop in society. [20] This based on seeing from the early history of Islam when many of the verses of the Quran, which are representative of God's will, make room for 'urf to play a role, many verses of the Quran that confirm the habits of the Arabs, for example; the ability to buy and sell that already existed before Islam, justified alliances as in the mudlabah contract, buying and selling, ijjrah and others, there are also many hadiths of the Prophet SAW that recognize the existence of $\mathrm{f}$ ' urf that has applied in society. In essence, the 'urf is not contrary to the arguments of the syara texts' in the Quran and hadith

\section{6) Qaul Shahabi}

Qaul Shahabi is one of the methods of law-oriented special method in the form of opinions from certain Prophet's friends. If it is defined, Qaul Shahabi is the matter of one Shahabah expressing an opinion and then spreading among other shahabahs, without being known of a shahabah who opposed it. [23] Qaul Shahabi is applied in contemporary fiqh, one of which is related to the practice of buying and selling credit systems that are punished illegally based on the opinions of Hanafiyah, Malikiyah and Syafiiyyah Ulama referring to qaul Aisyah r.a. [25]

\section{B. The Epistemology of Science}

In obtaining a more detailed explanation of the epistemology of science, Nidhal Guessoum explained his 
experience about science. According to him, science simply defined as a human effort to build an objective explanation of the world around it. This definition is in line with what Ziauddin Sardar explained that science is an organized, systematic, and orderly model of inquiry based on experimentation and empiricism that creates a result that can then be tested and redesigned and applies universally to all cultures. From this problem arises when science is only limited to the natural sciences. [26] Therefore, psychology and economics, politics and other disciplines that which not based on nature are not science.

Because the aspect of the nature of science does not get clarity and confusion, then to get clarity about the criteria of science, the primary and most essential characteristics of science lie in the methods and processes built in them. That is a process that is often called the scientific method. Scientific methods include observation of phenomena and data collection, hypothesis making, testing of hypotheses, and refinement of hypotheses. [26]

Pervez in his book Islam and Science explains the epistemology of science by explaining the sequence of elements that exist in science. Some of these elements include:

1) Facts; The existence of science stems from the existence of facts in this world. Facts can come from observations of an object which is a scientific fact as well so new facts emerge as a result of these observations. As an example of the discovery of facts about satellite forms that surround the planet Jupiter after a long period of observation of Jupiter.

2) Law; Law is a relationship that contained in a group of facts. For example, Mendel's law which states that in sexual processes, innate characteristics must be mediated by units transmitted from mother to offspring and combined in all possible ways.

3) Hypothesis; the hypothesis is a temporary assumption that gives an initial understanding of what is being studied, and which will be tested by observation or experimentation. For example: The level of rainfall in a place will be higher if more people perform istisqa prayers. In order to test the hypothesis, adequate data must be collected and then analyzed accurately.

4) Theory; what is meant by theory is a significant conceptual scheme that places thinking and provides a complete picture in the domain of validity. Besides, the theory must also be consistent with all known experimental and observational data.

5) Induction and Deduction; both induction and deduction are methods of gathering knowledge. The difference is induction to draw general conclusions from specific facts. Induction is a specific conclusion from general facts.

6) Scientific Method; Scientific methods are steps that must be found to produce something scientific or scientific. These steps include problem identification, literature review, preparation of an observation framework, hypothesis, and conclusion. [8]

\section{THE DISCUSSION OF EPISTEMOLOGY OF FIQH AND SCIENCE IN CONTEMPORARY FIQH IN INDONESIA}

In the realm of epistemology, there are at least some similarities between fiqh and science. Both, both figh and science are products or results of human thought as subjects. The difference is, if fiqh has a material source in the form of revelation, the source science is nature. Even if traced more deeply, both revelation and nature come from the same source, namely God. When fiqh is a dynamic area in Islamic law, fiqh certainly cannot ignore something that can achieve its objectives, namely legal products. Something that is possible, including science, when in the process of ijtihad, the science-based analysis is need that can help fiqh to achieve the truth of nisby.

Similarly, the relationship between figh and science. In the realm of epistemology, the application and implementation of fiqh by using legal methodology must use modern science as a tool. A review of the sources of fiqh from hadith and the Quran with scientific methodology is also essential. The occurrence of offense between fiqh and science in the realm of epistemology can be seen and taken into consideration in several cases of Islamic law, especially in Indonesia. Among these legal cases such as illegitimate halal considerations in a legal dimension using modern science theory in medical science. The most recent is the determination of the Rubella vaccine law. MUI's Fatwa No. 33 of 2018 About Rubella Vaccine states that the use of vaccines that use pigs and their derivatives is illegal. The use of MR Vaccine products from the Serum Institute of India (SII) is unlawful because the production process uses ingredients derived from pigs. Use of MR Vaccine products from the Serum Institute of India (SII), at this time, are permitted (changed) for three reasons.

A. There is a condition of coercion (dlarurat syar'iyyah).

B. Not yet found halal and sacred MR vaccine.

C. There is information from experts who are competent and trusted about the dangers caused by not being immunized and the absence of a halal vaccine.

Besides, the fatwa also includes a note that the ability to use MR vaccine as referred to in number 3 does not apply if a halal and sacred vaccine found.

In addition to the Rubella vaccine case, consideration of the Qibla direction for prayer using a scientific approach in the form of spherical geodesy and trigonometry, consideration of maslaha and determination of dzaria as a legal methodology method by using scientific theories, and so forth. It is also possible to develop developments on the unclean concept in the view of Islamic law, with the consideration of modern health science. Of course, with some notes that the involvement of science in Islamic law, will not be able to shift the power of the provisions of the Sharia based on certain arguments (qath'i).

\section{STRENGTHENING THE INTEGRITY OF SCIENCE-BASED CONTEMPORARY FIQH STUDIES}

As is well known, the Islamic sciences from the beginning of its spread have experienced progressive dynamics. Among the indicators of the dynamics of Islamic sciences in the 
present context is the development of various Islamic scientific disciplines by Prof. Harun Nasution classified as basic science such as interpretation, the science of hadith, the science of kalam, mysticism, Islamic philosophy, and a few branches of sciences. [27] Activities continue and developed by Muslim scientists from classical times to the present, even the development of Islamic sciences is more open, creative and bright, not only in one scientific family but also spread towards the development of science with its various disciplines when this. Concretely, there is a spirit towards the integration of religious and general science, the elimination of dichotomy between the two.

Within this perspective, the tradition of Islamic scholarship, especially in the field of law, is considered as wealth and spiritual power that needs to be preserved and maintained. Tradition is an authoritative source of mental strength to resist various dynamics of change and development in all aspects of life and human life. Moreover, the study in the field of law with its various variants is an ideal-effective area to sow and maintain the continuity of teaching practices and the development of Islamic traditions.

Therefore, creative and innovative efforts in maximizing the development of Islamic legal studies through various approaches must continue to be promoted, especially in making the classification of the relationship between scientific development (science and technology) and the universe (human and its environment), including social and historical approaches to reality. Even so, there are things that are no less important in such activities, namely the strengthening of the community's ongoing socialization and education efforts on the above. Given the condition of the religious spirituality of the people that is less intact and tends to be stagnant and its diverse experiences are isolated, it is not integrate with the reality of its life. Because this has caused an adverse impact on the trend of development of thought among followers of the Islamic schools, most of whom are reluctant to escape from the tradition that is taqlid and dogmatic. Moreover, such conditions further aggravated by the still firm grip of group fanaticism among those who are increasingly stagnating and thinking and thinking of the people. As a result, the formulation or descriptions of religious decisions that are different from the essence of diversity that has been carried out by classical Muslim scientists. Even if there is a fatwa stated, even by institutions that have authority tend to be rejected or ignored.

In conducting studies of Islamic law, Muslim scientists today or even Muslims in Indonesia are most willing and able to see the building of classical Islamic legal thought critically as salaf scholars develop critical traditions in their day. They would quickly see that the pyramid shape studies of classical Islamic law appear to be minus the nuances of historical thought and minus the social approach. [28] Whereas the Quran has taught everything through sociological and historical approaches, namely through the study of asbab nuzul verse, in addition to the normative approach.

Based on the description above, unusual if the people faced with the challenges of contemporary science such as universal humanitarian issues, religious pluralism, structural poverty or environmental damage, etc. tend to be a priori or based from various reasons and considerations such as about polemics Regarding whether or not the prohibition of measles and rubella (MR) vaccines discussed. Resulting in some parents being unwilling to give their children immunization because the vaccine is feared to be false or has no halal certificate.

As experts say, it is stated that measles and rubella are infectious diseases transmitted through the respiratory tract caused by viruses. Measles can cause serious complications such as diarrhea, pneumonia (pneumonia), inflammation of the brain (encephalitis), blindness and even death. While rubella is usually a mild disease in children, but if infecting pregnant women in the first trimester or early pregnancy can cause miscarriage or congenital disabilities in babies born, which is known as Congenital Rubella Syndrome, including heart and eye disorders, deafness and developmental delays. Deputy Secretary-General of the MUI Center for Fatwa, Sholahudin Al-Aiyub explained that it turns out that from the materials used for the production process of rubella vaccine several ingredients are considered critical regarding halal, which is related to the problem of trypsin and gelatin derived from pig enzymes. Moreover, therefore, the Central MUI states in its fatwa that the law of Measle Rubella (MR) vaccine is haram, but its use is permissible because of emergency by looking at the conditions and considerations that exist, including:

A. There is no halal MR vaccine production to use;

B. There is no treatment for measles and rubella, but both can prevent through immunization with MR vaccine;

C. The impact of Rubella disease must be watched carefully, considering that in the last five years there have been approximately 55,000 cases of MR, (Rubella is usually a mild disease in children, but if infecting pregnant women in the first trimester or early pregnancy can cause miscarriages or congenital defects in infants who were born, known as Congenital Rubella Syndrome, including heart and eye disorders, deafness and developmental delays;

D. In Indonesia, especially in the Papua region in 2017, measles had endemic and caused hundreds of deaths;

E. From data from the Ministry of Health, between 20102015 there were 23,000 cases of measles and 3000 Rubella cases but Unicef Indonesia's Immunization Specialist, dr. Kenny Peetosutan stated that the estimated number of measles and rubella could be higher because many cases are not reported. While in Southeast Asia and Africa, rubella cases have reached 120,000 each year.

However, not all parties responded positively to the Central MUI fatwa, one of which was the Riau Islands MUI which still insisted on calling on Muslims not to participate in measles and Rubella immunizations to be held by the government so that halal vaccines obtained. Departing from the "scientific" description of the legal fatwa, the government's measles and rubella vaccine immunization programs should be realized well and smoothly, but the facts are not the same. This is certainly contradictory.

Looking at the history of the development of Islamic law, it is indeed not easy to draw conclusions that from the very beginning Islamic legal thought could not be separated from the domination of political power. However, the essence and 
substance of divine thought manifested in social ethics, and religious spirituality should ideally be inherent in the study of Islamic law as applicable in the study and historicity of the Quran, which tends to be comprehensive, holistic and inclusive.

The dimensions of Islamic legal thought are more complete and have various factors that surround the entire life of the people, both politically, sociologically, psychologically, philosophically and theologically. Therefore, an up to date study of Islamic law is one that can build a balance between theocentric discourse and anthropocentric discretion, namely the benefit of the people and rahmatan lil il alamin.

\section{CONCLUDING REMARKS}

The existence of a conflict between religion and science has in some way caused the emergence of distance between the two. Even at an alarming level, science and religion negate each other's truths. Science does not recognize the truth of religion and God because it is not empirical and cannot be examined. While religion also denies the truth of science because it is not based on absolute truth.

To eliminate or at least reduce the occurrence of conflicts between religions, especially Islam with science, the discourse on the interaction of Islam and science in three forms of interaction must be realized. I.e the Islamization of science, the scientification of Islam and Islamic science. The natural picture is when Europeans, some of whom have applied Islamic teachings in the form of cleanliness, hard work, etc., but they have not embraced Islam, it is necessary to be Islamized. Whereas the scientification of Islam by holding a renewal of outdated Islamic teachings by using current and modern makeup. Whereas Islamic science utilizing interaction and integration between science and Islam is by building science entirely with the foundation of revelation, namely the Quran and Sunnah. [2]

The Quran which incidentally had existed for hundreds of centuries ago, when modern science was not yet born, turned out to have a verse that explained a clear and comprehensive concept of the universe. Information about nature originating from the Quran was ultimately proven right by the world of modern science. Whereas verses relating to nature in the Quran according to Muslim writers, there are about 750 verses. Based on this, Muhammad Iqbal believes that the methodology and epistemology in the Quran are empirical and rational. [26]

Based on this, the scientific study of Quranic verses relating to nature is a point that must be done by Muslim scientists. This is referred to as Islamic science. Strengthening philosophical pillars from ontology, epistemology, and axiology requires its presence in order to revive Islamic science (QS. Al Haqqah 38-39). The unseen realm which turns out to be an essential aspect that cannot be ignored at all by Islam must also be an aspect of concern in Islamic science. In the realm of axiology, Islamic science must lead to the recognition of God with the pattern of His creation and knowing the true nature of all things. Whereas the epistemology realm includes methods, Islamic science can use the method of sight with eyes, hearing with ears and reflection with the heart (QS. An Nahl : 78). Borrowing the term Abid Al Jabiri with its three approaches, burhani, bayani and irfani. Moreover, Islamic science must accommodate these three approaches using three methods. Burhani and bayani with eyes and ears. While irfani with heart.

In the end, the existence of fiqh as an interpretation and explanation for the Sharia should be able to accommodate other disciplines as a tool to produce a new legal product. Moreover, the dynamic nuance that is characteristic of figh should be able to make the legal process of dynamism take place dynamically, according to conditions and situations.

\section{REFERENCES}

[1] J. F. Haught, Perjumpaan Sains dan Agama, Bandung: Mizan Pustaka, 2004

[2] A. Purwanto, Nalar Ayat-Ayat Semesta, Bandung: Mizan, 2015.

[3] A. Syairazi, Al Luma’ Fi Ushul Al Fiqh, Beirut: Dar Ibn Katsir, 1995.

[4] M. K. Afandi, Dari Teori Ushul Menuju Fiqh, Kediri: Santri Salaf Press, 2013

[5] B. Yuwono, Ilmuwan Islam Pelopor Sains Modern, Jakarta: Pustaka Kalami, 2005.

[6] M. o. E. o. RI, Kamus Besar Bahasa Indonesia, Jakarta: Balai Pustaka, 2008.

[7] U. A. Janie, "Ilmu Pengetahuan dan Teknologi dalam Perspektif Pemikiran Islam," in Menyatukan Kembali Ilmu-ilmu Agama dan Umum, J. Wahyudi, Ed., Yogyakarta, Suka Press, 2003.

[8] P. Hoodbhoy, Islam dan Sains Pertarungan Menegakkan Rasionalitas, Bandung: Pustaka, 1997.

[9] M. Adib, Filsafat Ilmu: Ontologi, Epistemologi, Aksiologi, dan Logika Ilmu Pengetahuan, Yogyakarta: Pustaka Pelajar, 2010.

[10] S. A. Syarbini, Mughni al Muhtaj, Beirut: Dar al Ma'rifah, 1997.

[11] A. A. Bilal, Asal Usul dan Perkembangan Fiqh, Bandung: Nusamedia, 2005.

[12] W. A. Zuhaili, Ushul Al Fiqh al Islami, Beirut: Dar al Fikr, 1987.

[13] A. A. An-Na'im, Dekonstruksi Syariah, Wacana Kebebasan Sipil Hak Asasi Manusia dan Hubungan Internasional dalam Islam, Yogyakarta: LKIS, 1990.

[14] Al-Ghazali, Al-Mustashfa min Ilmi Al-Ushul, Beirut: Dar Al-Kutub Al-Ilmiyah, 2010.

[15] Al-Amidi, Al-Ihkam fi Ushul al-Ahkam, Kairo: Matba'ah al-Ma'arif, 1991.

[16] A. Helim, "Otoritas Mashlahah dalam Membangun Fikih Dinamis," Jurnal Studi Agama dan Masyarakat, vol. 03, no. 02, pp. 118-166, 2006.

[17] A. I. I. Asy-Syathibi, Al-Muwafaqat fi Ushul Asy-Syari'ah, Kairo: Maktabah At-Taufiqiyah, 2003.

[18] A. K. An-Namlah, Al-Muhadzab fi Ilmi Ushul Al-Fiqh Al-Muqaran, Riyadh: Maktabah Ar-Rusyd, 1999.

[19] M. Louis, al-Munjid fi al lughah wa al-Alam, Beirut: Maktabah Dar Al Fikr.

[20] A. W. Khalaf, 'Ilm Ushul al-Fiqh, Kairo: Maktabah Dar al-Qalam, 1978.

[21] A. W. Munawwir, Kamus Al-Munawwir, Surabaya: Pustaka Progressif, 1997.

[22] M. H. al-Burhani, Sadd adz-Dzara'i' fi asy-Syari'ah al-Islamiyah, Damaskus: Darul Fikr, 1985.

[23] J. Aripin, Kamus Ushul Fiqh dalam dua Bingkai Ijtihad, Jakarta: Kencana Prenada Media Grup, 2012.

[24] I. Mandzur, Lisan al-'Arab, Beirut: Dar al-Shadir, 1990.

[25] M. C. Nizar, "Qaul Shahabi dan Aplikasinya dalam Fiqh Kontemporer. . Vol. 1 No. 1," Jurnal Ulul Albab: Jurnal Studi dan Penelitian Hukum Islam, vol. 01, no. 01, pp. 20-38, 2017.

[26] N. Guessoum, Islam dan Sains Modern, Bandung : Al Mizan, 2014

[27] H. Nasution, "Klasifikasi Ilmu dan Tradisi Penelitian Islam : Sebuah Perspektif" Dalam Tradisi Baru Penelitian Agama Islam Tinjauan Antar Disiplin Ilmu, Jakarta: Nuansa, 2001.

[28] H. Hanafi, Dirasat Islamiyyah, Kairo: Maktabah al-Anjilu alMishriyyah. 